\title{
Effects on surface atmospheric photo-oxidants over Greece during the total solar eclipse event of 29 March 2006
}

\author{
P. Zanis ${ }^{1}$, E. Katragkou ${ }^{2}$, M. Kanakidou ${ }^{3}$, B. E. Psiloglou ${ }^{4}$, S. Karathanasis ${ }^{5}$, M. Vrekoussis ${ }^{3,}{ }^{*}$, E. Gerasopoulos ${ }^{4}$, \\ I. Lisaridis ${ }^{2}$, K. Markakis ${ }^{2}$, A. Poupkou ${ }^{2}$, V. Amiridis ${ }^{4}$, D. Melas ${ }^{2}$, N. Mihalopoulos ${ }^{3}$, and C. Zerefos ${ }^{4}$ \\ ${ }^{1}$ Department of Meteorology and Climatology, Aristotle University of Thessaloniki, Greece \\ ${ }^{2}$ Laboratory of Atmospheric Physics, Aristotle University of Thessaloniki, Greece \\ ${ }^{3}$ Environmental Chemical Processes Laboratory, Department of Chemistry, University of Crete, Greece \\ ${ }^{4}$ National Observatory of Athens, Athens, Greece \\ ${ }^{5}$ Region of Central Macedonia, Thessaloniki, Greece \\ *now at: Institute of Environmental Physics and Remote Sensing IUP/IFE, University of Bremen, Germany
}

Received: 20 July 2007 - Published in Atmos. Chem. Phys. Discuss.: 2 August 2007

Revised: 26 November 2007 - Accepted: 26 November 2007 - Published: 10 December 2007

\begin{abstract}
.
This study investigates the effects of the total solar eclipse of 29 March 2006 on surface air-quality levels over Greece based on observations at a number of sites in conjunction with chemical box modelling and 3-D air-quality modelling. Emphasis is given on surface ozone and other photooxidants at four Greek sites Kastelorizo, Finokalia (Crete), Pallini (Athens) and Thessaloniki, which are located at gradually increasing distances from the path of the eclipse totality and are characterized by different air pollution levels. The eclipse offered the opportunity to test our understanding of air pollution build-up and the response of the gas-phase chemistry of photo-oxidants during a photolytical perturbation using both a photochemical box model and a regional air-quality offline model based on the modeling system WRF/CAMx. At the relatively unpolluted sites of Kastelorizo and Finokalia no clear signal of the solar eclipse on surface $\mathrm{O}_{3}, \mathrm{NO}_{2}$ and $\mathrm{NO}$ concentrations can be deduced from the observations while there is no correlation of observed $\mathrm{O}_{3}, \mathrm{NO}_{2}$ and $\mathrm{NO}$ with observed global radiation. The box and regional model simulations for the two relatively unpolluted sites indicate that the calculated changes in net ozone production rates between eclipse and non eclipse conditions are rather small compared to the observed short-term ozone variability. Furthermore the simulated ozone lifetime is in the range of a few days at these sites and hence the solar eclipse effects on ozone can be easily masked by local and regional transport. At the polluted sites of Thessaloniki and Pallini, the solar eclipse effects on $\mathrm{O}_{3}, \mathrm{NO}_{2}$ and $\mathrm{NO}$ concentrations are revealed from both the measurements and modeling with the net effect being a decrease in $\mathrm{O}_{3}$ and $\mathrm{NO}$ and an increase in $\mathrm{NO}_{2}$ as $\mathrm{NO}_{2}$ formed
\end{abstract}

Correspondence to: P. Zanis

(zanis@auth.gr) from the reaction of $\mathrm{O}_{3}$ with $\mathrm{NO}$ while at the same time $\mathrm{NO}_{2}$ is not efficiently photolysed. This result is also supported by a positive correlation of observed global radiation with $\mathrm{O}_{3}$ and $\mathrm{NO}$ and a negative correlation with $\mathrm{NO}_{2}$. It is evident from the 3-D air quality modeling over Greece that the maximum effects of the eclipse on $\mathrm{O}_{3}, \mathrm{NO}_{2}$ and $\mathrm{NO}$ are reflected on the large urban agglomerations of Athens, and Thessaloniki where the maximum of the emissions occur.

\section{Introduction}

The effects of a solar eclipse on total ozone column and stratospheric ozone have been reported by several authors (Zerefos et al., 2000 and references therein). However, there are only a limited number of studies concerning the solar eclipse induced effects on tropospheric ozone and other photooxidants (Srivastava et al., 1982; Abram et al., 2000; Fabian et al., 2001; Zanis et al., 2001; Zerefos et al., 2001).

During a solar eclipse solar radiation changes may affect tropospheric ozone in several ways and timescales. Tropospheric ozone concentrations may be directly affected by the $\mathrm{JO}^{1} \mathrm{D}$ and $\mathrm{JNO}_{2}$ photolysis rate constants changes and indirectly by the $\mathrm{NO}_{\mathrm{x}}$ and $\mathrm{HO}_{\mathrm{x}}$ budget modifications. Both change the relative strength of sources and sinks of tropospheric $\mathrm{O}_{3}$. A fast response of tropospheric ozone to solar eclipse stems from the decrease of $\mathrm{JNO}_{2}$ which induces a perturbation from the photostationary steady state of $\mathrm{O}_{3}, \mathrm{NO}$ and $\mathrm{NO}_{2}$ in reactions (R1), (R2) and (R3):

$$
\begin{aligned}
& \mathrm{NO}_{2}+\mathrm{hv}(\lambda<424 \mathrm{~nm}) \rightarrow \mathrm{O}\left({ }^{3} \mathrm{P}\right)+\mathrm{NO} \\
& \mathrm{O}\left({ }^{3} \mathrm{P}\right)+\mathrm{O}_{2}+\mathrm{M} \rightarrow \mathrm{O}_{3}+\mathrm{M} \\
& \mathrm{NO}+\mathrm{O}_{3} \rightarrow \mathrm{NO}_{2}+\mathrm{O}_{2}
\end{aligned}
$$

Published by Copernicus Publications on behalf of the European Geosciences Union. 
As a direct consequence the primary pollutant $\mathrm{NO}$ destroys $\mathrm{O}_{3}$ through the titration reaction (R3) without $\mathrm{O}_{3}$ being resumed through the $\mathrm{NO}_{2}$ photolysis (R1). This fast ozone response to solar eclipse can be clearly identified in relatively polluted sites such as urban and suburban sites.

A slower response of tropospheric ozone to solar eclipse can result from changes in the UV-B radiation which affect the photolysis rate constant $\mathrm{JO}^{1} \mathrm{D}$ that photodissociates ozone in the near UV. Changes in UV-B induce changes in the direct ozone loss rate via reaction (R4), of the production rate of the hydroxyl radical $\mathrm{OH}$ (in the presence of water vapor) via reaction (R5) and of the hydroperoxy radicals via reactions (R6) and (R7):

$\mathrm{O}_{3}+\mathrm{hv}(\lambda<320 \mathrm{~nm}) \rightarrow \mathrm{O}^{1} \mathrm{D}+\mathrm{O}_{2}$

$\mathrm{O}^{1} \mathrm{D}+\mathrm{H}_{2} \mathrm{O} \rightarrow 2 \mathrm{OH}$

$\mathrm{OH}+\mathrm{CO} \rightarrow \mathrm{H}+\mathrm{CO}_{2}$

$\mathrm{H}+\mathrm{O}_{2}+\mathrm{M} \rightarrow \mathrm{HO}_{2}+\mathrm{M}$

In turn, changes in the $\mathrm{OH}$ and $\mathrm{HO}_{2}$ concentrations induce changes in the rates of ozone loss pathways via reactions (R8) and (R9):

$\mathrm{HO}_{2}+\mathrm{O}_{3} \rightarrow \mathrm{OH}+2 \mathrm{O}_{2}$

$\left.\mathrm{OH}+\mathrm{O}_{3} \rightarrow \mathrm{HO}_{2}+\mathrm{O}_{2}\right)$

and in the ozone production pathway via reaction (R10) when $\mathrm{NO}$ is present :

$\mathrm{HO}_{2}+\mathrm{NO} \rightarrow \mathrm{OH}+\mathrm{NO}_{2}$

The photolysis of other species which are secondary sources of radicals such as $\mathrm{HCHO}(\lambda<330 \mathrm{~nm})$ or $\mathrm{CH}_{3} \mathrm{CHO}$ $(\lambda<330 \mathrm{~nm})$ via radical formation can also affect the surface ozone concentrations. Therefore, surface ozone is expected to be susceptible to solar radiation changes observed during eclipse events.

Zanis et al. (2001) showed that during the eclipse of 11 August 1999 the surface ozone displayed a decrease of around $10-15 \mathrm{ppbv}$ at the urban site of Thessaloniki, Greece (90\% sun disk obscuration) while at the rural elevated site of Hohenpeissenberg, Germany (99.4\% sun disk obscuration) the actual surface ozone data did not show any clear eclipse effect. During the 11 August 1999 eclipse event, Mavrakis et al. (2004) found ozone responses to the eclipse over the greater Athens area that varied in terms of timing and intensity as a function of the local emissions, the local topography and the distance from the seashore. Photochemical box model simulations for Freising-Weihenstephan, Germany for the same eclipse event suggested a $4 \mathrm{ppb}$ reduction in the net $\mathrm{O}_{3}$ production until the end of the eclipse. Both measurements and model simulations showed that the partitioning of $\mathrm{NO}_{\mathrm{x}}$ between $\mathrm{NO}$ and $\mathrm{NO}_{2}$ was determined almost exclusively by the variations in $\mathrm{JNO}_{2}$ (Fabian et al.,
2001). Furthermore highly time-resolved measurements of $\mathrm{O}_{3}, \mathrm{OH}$ and $\mathrm{JO}^{1} \mathrm{D}$ were made at ground level during a $97 \%$ solar eclipse at Silwood Park, Ascot, UK on 11 August 1999 (Abram et al., 2000). The observed change in the concentration of $\mathrm{OH}$, which decreased to below the detection limit of the instrument at the maximum of the solar eclipse and the decrease of ozone shortly after maximum eclipse provided a clear demonstration of the fast photochemistry of the planetary boundary layer.

The present work investigates the chemical effects during the total solar eclipse of 29 March 2006 on surface ozone and other photo-oxidants over Greece. Taking advantage that part of southeastern Greece experienced the totality of solar eclipse, combined measurements of air quality and meteorological parameters were organized at sites located at different distances from the eclipse path. The different solar obscuration at each site combined with a variety of air quality measurements has enabled a thorough representation and investigation of the response of photochemistry to an abrupt photolytical perturbation.

\section{Data and methods}

\subsection{Description of measurements}

The eclipse effects during the 29 March 2006 on the biosphere and on various atmospheric layers have been investigated in the frame of a field experiment over Greece. Details about the organization of the experimental campaigns, the measurement sites, eclipse path maps as well as information about the eclipse circumstances for each location are given in an overview paper by Gerasopoulos et al. (2007). The measurements used in this study were carried out at two urban sites, Pallini (greater Athens area) and Thessaloniki and at two marine rural sites, Finokalia (Crete) and Kastelorizo Island.

The Institute for Environmental Research and Sustainable Development (IERSD) of the National Observatory of Athens (NOA), conducted measurements of gas-phase air pollutants using their automobile station in the framework of the eclipse campaign at Kastelorizo Island. This air quality monitoring includes measurements of (i) ozone $\left(\mathrm{O}_{3}\right)$, (ii) nitrogen oxides ( $\mathrm{NO}$ and $\mathrm{NO}_{2}$ ), and (iii) carbon monoxide (CO), with the use of HORIBA Air Pollution Monitoring Systems (AP-360 series). The uncertainties of the field measurements of $\mathrm{O}_{3}, \mathrm{NO}_{\mathrm{x}}$ and $\mathrm{CO}$ for the 1-minute averages are $\pm 3.2 \mathrm{ppbv}$ for $\mathrm{O}_{3}, \pm 4.0 \mathrm{ppbv}$ for $\mathrm{NO}_{\mathrm{x}}$ and $\pm 0.21 \mathrm{ppmv}$ for $\mathrm{CO}$ while the detection limits are $0.5 \mathrm{ppbv}$ for $\mathrm{O}_{3}$, and $\mathrm{NO}_{\mathrm{x}}$ measurements and $0.2 \mathrm{ppmv}$ for $\mathrm{CO}$. All air quality analyzers were carefully calibrated on site using specific gases of known concentration. In addition, various meteorological observations were carried out from a fully automated meteorological station: (i) air temperature and relative humidity, (ii) atmospheric pressure, (iii) wind speed and direction 
(6 $\mathrm{m}$ height), (iv) $\mathrm{u}, \mathrm{v}$ and $\mathrm{w}$ wind components using an ultrasound sonic anemometer, (v) total solar radiation on a horizontal surface, and (vi) direct solar radiation. All parameters were recorded with 1 min time resolution, except for the ultra-sound sonic anemometer measuring at a frequency of $21 \mathrm{~Hz}$.

The monitoring station of the University of Crete at Finokalia, Lasithi, Crete is located $70 \mathrm{~km}$ eastward of Heraklion (about 140 thousand inhabitants) and $25 \mathrm{~km}$ west of Agios Nikolaos (about 20 thousand inhabitants), the nearest big cities in the area. These cities do not have any noticeable influence on the site due to the prevailing north winds. The station is located on the north coast of Crete exposed to the sea from $270^{\circ}-90^{\circ}$ (W-E). An automated meteorological station enables measurements of air temperature, relative humidity, wind speed and direction and total solar radiation. The photodissociation rates of $\mathrm{NO}_{2}\left(\mathrm{JNO}_{2}\right)$ and $\mathrm{O}_{3}$ to $\mathrm{O}^{1} \mathrm{D}\left(\mathrm{JO}^{1} \mathrm{D}\right)$ as well as Radon-222 $\left({ }^{222} \mathrm{Rn}\right), \mathrm{O}_{3}$, $\mathrm{NO}, \mathrm{NO}_{2}, \mathrm{PM}_{10}$, and other chemical tracers are also monitored and registered every $5 \mathrm{~min}$ ( $2 \mathrm{~h}$ for Radon) (Mihalopoulos et al., 1997; Gerasopoulos et al., 2005, 2006). Details about the station and the instrumentation are presented at http://finokalia.chemistry.uoc.gr/.

The Air Quality Monitoring Network of Athens International Airport (AIA) operates since October 1998 and consists of five permanent monitoring stations and one mobile monitoring station. The permanent stations are installed in the Municipalities of Glyka Nera, Koropi, Markopoulo, Pallini and Spata while the mobile station is currently located at the airport premises. A wide range of pollutants are operationally monitored using HORIBA Air Pollution Monitoring Systems (AP-360CE) including: nitrogen oxides (NO and $\left.\mathrm{NO}_{2}\right)$, sulphur dioxide $\left(\mathrm{SO}_{2}\right)$, carbon monoxide $(\mathrm{CO})$, ozone $\left(\mathrm{O}_{3}\right)$, particulate matter $\left(\mathrm{PM}_{10}\right)$, hydrocarbons $(\mathrm{HCs})$ and benzene-toluene-xylene (BTX). Furthermore the meteorological parameters including wind speed and direction, air temperature, relative humidity, rainfall, solar radiation and atmospheric pressure are also measured.

In the Greater Area of Thessaloniki air quality measurements are carried out regularly since 2001 by the Region of Central Macedonia (RCM). This monitoring network consists of eight fixed monitoring stations equipped with instruments that measure ambient levels of gaseous $\left(\mathrm{SO}_{2}, \mathrm{NO}_{2}\right.$, $\left.\mathrm{NO}, \mathrm{CO}, \mathrm{O}_{3}\right)$ and particulate matter $\left(\mathrm{PM}_{10}\right.$ and TSP) air pollutants using a HORIBA Air Pollution Monitoring Systems (AP-360 series). Most of the stations also collect meteorological data (wind direction, horizontal wind speed, ambient temperature and humidity). In this study we used the data collected at the air quality measurement station situated at the roof of the Physics Department of Aristotle University of Thessaloniki (AUTH). During the day of the eclipse event, the air quality (NO, $\mathrm{NO}_{2}$ and $\mathrm{O}_{3}$ ) and meteorological (wind speed, wind direction, air temperature and relative humidity) measurements were recorded with 1 minute time resolution. The field measurements of $\mathrm{O}_{3}$ and $\mathrm{NO}_{\mathrm{x}}$ at Pallini, Thessa- loniki and Finokalia exhibit similar uncertainties and detections limits to those referred above for Kastelorizo.

\subsection{Box modelling}

The impact of the observed changes in meteorological and chemical parameters during the eclipse on the oxidant levels has been studied with a chemical box model (ECPL box model; Poisson et al., 2001; Tsigaridis and Kanakidou, 2002; Vrekoussis et al., 2004). The commercially available software FACSIMILE (Curtis and Sweetenham, 1988), which uses automatic time step selection and error control appropriate to solve stiff equations like the system of non linear chemical reactions occurring in the troposphere, was used to solve the differential equations with a high accuracy required for chemistry studies. The chemistry scheme is a condensed chemical mechanism (about 300 chemical reactions and 140 chemical species). It is able to simulate boundary layer photochemistry of ozone, water vapour, nitrogen oxides, carbon monoxide and volatile organics as well as the chemistry of sulphur. In addition to background $\mathrm{O}_{3} / \mathrm{NO}_{\mathrm{x}} / \mathrm{OH} / \mathrm{CO}$ and $\mathrm{CH}_{4}$ chemistry, it also takes into account the oxidation chemistry of $\mathrm{C}_{1}-\mathrm{C}_{5}$ hydrocarbons including isoprene (Tsigaridis and Kanakidou 2002; Vrekoussis et al., 2004, 2006) and biogenic sulphur oxidation mechanisms (Sciare et al., 2000a). Oxidation of volatile organic compounds (VOC) by all three major oxidants $\left(\mathrm{O}_{3}, \mathrm{OH}\right.$ and $\mathrm{NO}_{3}$ ) is considered when applicable. Heterogeneous reactions of peroxy and nitrate radicals are taken into account as explained by Tsigaridis and Kanakidou (2002) and Vrekoussis et al. (2004).

The condensed chemistry scheme of the box model has been evaluated for its ability to compute oxidant fields by comparison to a detailed chemistry scheme for C1-C5 chemistry as shown in Poisson et al. (2001) as well as to several field observations under different conditions in the boundary layer (Poisson et al., 2001; Sciare et al., 2000b; Tsigaridis and Kanakidou, 2002; Vrekoussis et al., 2004; 2006).

Ethene, propene, ethane, propane and butanes diurnal mean mixing ratios, measured at Finokalia, Crete, in 2004 (Liakakou, 2007), are adopted in the model as initial conditions for all stations due to the absence of VOC data for the other locations. Formaldehyde (HCHO) mixing ratios have been initialised to $1 \mathrm{ppbv}$ (Lelieveld et al., 2002). This model version has been previously applied to evaluate on a seasonal basis the impact of isoprene chemistry on the oxidizing capacity of the area (Liakakou et al., 2007).

Chemistry box model simulations have been performed over a 3-day period around the eclipse occurrence over Finokalia. The first day of the simulation was used as spin up time. Observed meteorology, photodissociation rates of $\mathrm{NO}_{2}$ and $\mathrm{O}_{3}\left(\mathrm{JNO}_{2}\right.$ and $\left.\mathrm{JO}^{1} \mathrm{D}\right), \mathrm{NO}, \mathrm{NO}_{2}$ and $\mathrm{O}_{3}$ levels have been used as input to the model every $5 \mathrm{~min}$. Reaction rates driven by meteorological conditions are calculated online. The model has been applied to calculate the free 
radical levels in the marine boundary layer and evaluate their response to the eclipse. Simulations have been performed both by considering and by neglecting the perturbation of photodissociation rates caused by the solar eclipse.

Similar simulations have been also performed for the other observational sites, Kastelorizo, Pallini (Athens) and Thessaloniki for the day of the eclipse.

\subsection{Regional Air-quality modeling}

The regional air quality model simulations have been performed with the Comprehensive Air quality Model (CAMx version 4.40). CAMx ran with grid spacing over Greece in a spatial resolution of $10 \times 10 \mathrm{~km}$ and four fine nests with higher resolution $(2 \times 2 \mathrm{~km})$ over the Greater Athens and Thessaloniki areas, Kastelorizo and Finokalia. The domain's vertical profile contains 15 layers of varying thickness. Layer 1 is $22 \mathrm{~m}$ deep, layer 2 extends between 22 and $50 \mathrm{~m}$ and subsequent layer depths increase with height. The uppermost layer is $1.5 \mathrm{~km}$ thick and extends to about $8 \mathrm{~km}$.

The meteorological fields have been derived from the Weather Research and Forecasting (WRF version 2.1.2, January 2006) Model developed at the National Center for Atmospheric Research, operated by the University Corporation for Atmospheric Research. WRF has been modified accordingly to reproduce the event of eclipse (Founda et al., this issue). The first model domain covers the Balkan area $(55 \times 55$ grid boxes with $30 \times 30 \mathrm{~km}$ resolution), the second domain covers Greece (nested domain with $121 \times 121$ grid boxes and $10 \times 10 \mathrm{~km}$ resolution). The four domains with finer resolution $(2 \times 2 \mathrm{~km})$ cover the measuring sites (Athens, Thessaloniki, Kastelorizo, Finokalia). In the vertical WRF model 31 layers between surface and $18.5 \mathrm{~km}$ were considered.

Anthropogenic and biogenic gridded emissions have been compiled for a coarse master domain covering Greece $(98 \times 108$ cells, $10 \times 10 \mathrm{~km})$ and for the four nested grids with finer resolution $(2 \times 2 \mathrm{~km})$. Emission data for gaseous pollutants (NMVOC, $\mathrm{NO}_{\mathrm{x}}, \mathrm{CO}, \mathrm{SO}_{2}, \mathrm{NH}_{3}$ ) and particulate matter $\left(\mathrm{PM}_{10}\right)$ were estimated for different anthropogenic emission sectors such as transport, power plants, the industrial and central heating sectors. Anthropogenic emissions of the neighbouring countries (Albania, Bulgaria and Turkey) have been taken from the EMEP emission database. Diurnal biogenic emissions over Greece and neighbouring countries have been calculated for every month of the year following the EMEP/CORINAIR methodology (Poupkou et al., 2004). All emissions are injected in the first model layer of $22 \mathrm{~m}$ height.

Three days of simulation are regarded as "spin-up" time (26-28 March 2006) in order to eliminate the effect of initial conditions. Initial and boundary conditions corresponded to concentrations of clean air. The chemistry mechanism invoked is Carbon Bond version 4 (CB4) reviewed by Dodge (2000). This mechanism includes 117 reactions -11 of which are photolytic - and up to 67 species ( 37 gasses, 12 radicals and up to 18 particulates). Photolysis rates were derived for each grid cell assuming clear sky conditions as a function of five parameters: solar zenith angle, altitude, total ozone column, surface albedo, and atmospheric turbidity. The rates were taken from a large lookup table that spans the range of conditions for each of the five dimensions. This table has been developed using the TUV photolysis pre-processor following the discrete ordinates method (Madronich, 1993).

The major accomplishment of introducing the eclipse effect in the model parameterizations was to insert the eclipse path into the model's subroutines in such a way that affects only a specific area on Earth's surface in a time-dependent manner. The photolysis rate variation was introduced by the use of factor per(lat,lon,t), which was related to the distance from the centre of the eclipse shadow, the latter considered as a circle moving on Earth with a specific velocity. Every time the photolysis rates were calculated, the distance of each grid point from the centre of the shadow was changing according to the formula applied. Photolysis rates thus have been modified for the eclipse event (09:30-12:00 UTC) by multiplication of the clear-sky photolysis rates $J_{\text {clear }}$ with a factor per which actually simulated the differences in sun disk coverage and was given as a function of latitude, longitude and time per(lat,lon,t).

The presence of clouds modifies further $\mathrm{J}_{\text {clear }}$ according to the equation:

$\mathrm{J}=\operatorname{per}($ lat, lon, $\mathrm{t}) *\left[1+F_{c}\left(A_{c}-1\right)\right] * \mathrm{~J}_{\text {clear }}$

where $F_{c}$ is the cloud cover fraction - introduced into the model by the input of meteorological fields - and $A_{c}$ is the vertical cloud attenuation factor, calculated separately for above and within/below clouds:

$A c=1+(1-t) \cos \phi$ above cloud layer

$A c=1.6 t \cos \phi$ within /below cloud layer where $\phi$ is solar zenith angle and the energy transmission coefficient. A more detailed description of the calculation of photolysis rates and the cloud attenuation factor are given in CAMx User's Guide (2006).

In order to analyse the photochemical model performance the Process Analysis (PA) tool has been invoked. The PA tool, implemented in CAMx, allows for a better understanding of the complex interactions in different processes and simulation results within the context of model formulation (CAMx User's Guide, 2006). Besides the standard gaseous species concentrations involved in tropospheric chemistry $\left(\mathrm{NO}_{\mathrm{x}}, \mathrm{O}_{3}\right.$ and VOCs) PA allows retrieval of information on parameters calculated by $\mathrm{CAMx}$, like $\mathrm{O}_{3}$ production, photolysis rates and radical concentrations. 
Table 1. Observations and simulations with $\mathrm{CAMx}$ of $\mathrm{O}_{3}, \mathrm{NO}_{2}$ and NO averaged over the time window 09:30-12:00 UTC when the eclipse took place for the sites Kastelorizo, Finokalia, Pallini and Thessaloniki. The standard deviation is given in parenthesis. The mean bias between modelled and observed values, calculated from the formula $(1 / \mathrm{N}) \sum\left(\bmod _{i}-\mathrm{obs}_{i}\right)$ for the same time window, is also indicated as well as the maximum total solar obscuration for each site.

\begin{tabular}{llllc}
\hline & $\mathrm{O}_{3}$ (ppbv) & $\mathrm{NO}_{2}$ (ppbv) & $\mathrm{NO}(\mathrm{ppbv})$ & $\begin{array}{c}\text { Maximum solar } \\
\text { obscuration }(\%)\end{array}$ \\
\hline Kastelorizo & & & 100 \\
Obs & $68.60( \pm 4.26)$ & $1.57( \pm 1.40)$ & $0.02( \pm 0.01)$ & \\
CAMx & $51.74( \pm 0.58)$ & $0.17( \pm 0.01)$ & $0.39( \pm 0.28)$ & \\
Mean Bias & -16.01 & -1.73 & -0.41 & 95.6 \\
Finokalia & & & & \\
Obs & $42.72( \pm 2.48)$ & $0.34( \pm 0.13)$ & $0.07( \pm 0.02)$ & \\
CAMx & $43.48( \pm 0.55)$ & $0.30( \pm 0.04)$ & $0.05( \pm 0.02)$ & \\
Mean Bias & 1.19 & -0.05 & -0.02 & 75.1 \\
Pallini, Athens & & & & \\
Obs & $36.87( \pm 3.59)$ & $15.59( \pm 3.42)$ & $4.83( \pm 1.13)$ & \\
CAMx & $34.78( \pm 6.40)$ & $19.03( \pm 7.30)$ & $6.21( \pm 4.28)$ & \\
Mean Bias & -2.25 & 3.61 & 3.62 & \\
Thessaloniki & & & & \\
Obs & $43.47( \pm 4.31)$ & $12.11( \pm 2.69)$ & $1.89( \pm 1.16)$ & \\
CAMx & $42.48( \pm 3.35)$ & $11.75( \pm 2.80)$ & $3.22( \pm 0.50)$ & \\
Mean Bias & -1.80 & 3.10 & 5.41 & \\
\hline & & & & \\
\hline
\end{tabular}

\section{Results}

\subsection{Measurements}

The time series of measured $\mathrm{O}_{3}, \mathrm{NO}_{2}$ and $\mathrm{NO}$ and solar radiation for the four different sites during the day of eclipse are illustrated in Fig. 1 while the average concentrations of the chemical constituents during the time window of the eclipse from 09:30 to 12:00 UTC are shown in Table 1. Based on the $\mathrm{NO}_{\mathrm{x}}$ levels at these four sites the maritime stations of Finokalia and Kastelorizo can be considered as relatively unpolluted to semi-polluted sites while the suburban/urban stations of Pallini (Athens) and Thessaloniki are polluted sites. At Kastelorizo (Fig. 1a) no major signal of solar eclipse on surface $\mathrm{O}_{3}, \mathrm{NO}_{2}$ and $\mathrm{NO}$ concentrations can be deduced from the observations. The only striking features are the two pollution plumes with peak concentrations of $\mathrm{NO}_{\mathrm{x}}$ (about 90 and $15 \mathrm{ppbv}$ for $\mathrm{NO}_{2}$ and $\mathrm{NO}$, respectively) and the subsequent lower concentrations of $\mathrm{O}_{3}$ prior and just after the beginning of the solar eclipse. Similarly at Finokalia (Fig. 1b) no drastic changes are seen on $\mathrm{O}_{3}, \mathrm{NO}_{2}$ and $\mathrm{NO}$ concentrations due to the solar eclipse.

The solar eclipse effects on $\mathrm{O}_{3}, \mathrm{NO}_{2}$ and NO concentrations are more clearly marked on the measurements at Pallini station (Fig. 1c). $\mathrm{O}_{3}$ and $\mathrm{NO}$ concentrations show a gradual decrease from the first contact until the maximum coverage, while during the second phase ozone gradually increases reaching its prior to the eclipse levels. An opposite pattern is seen on the $\mathrm{NO}_{2}$ concentrations as the $\mathrm{NO}_{2}$
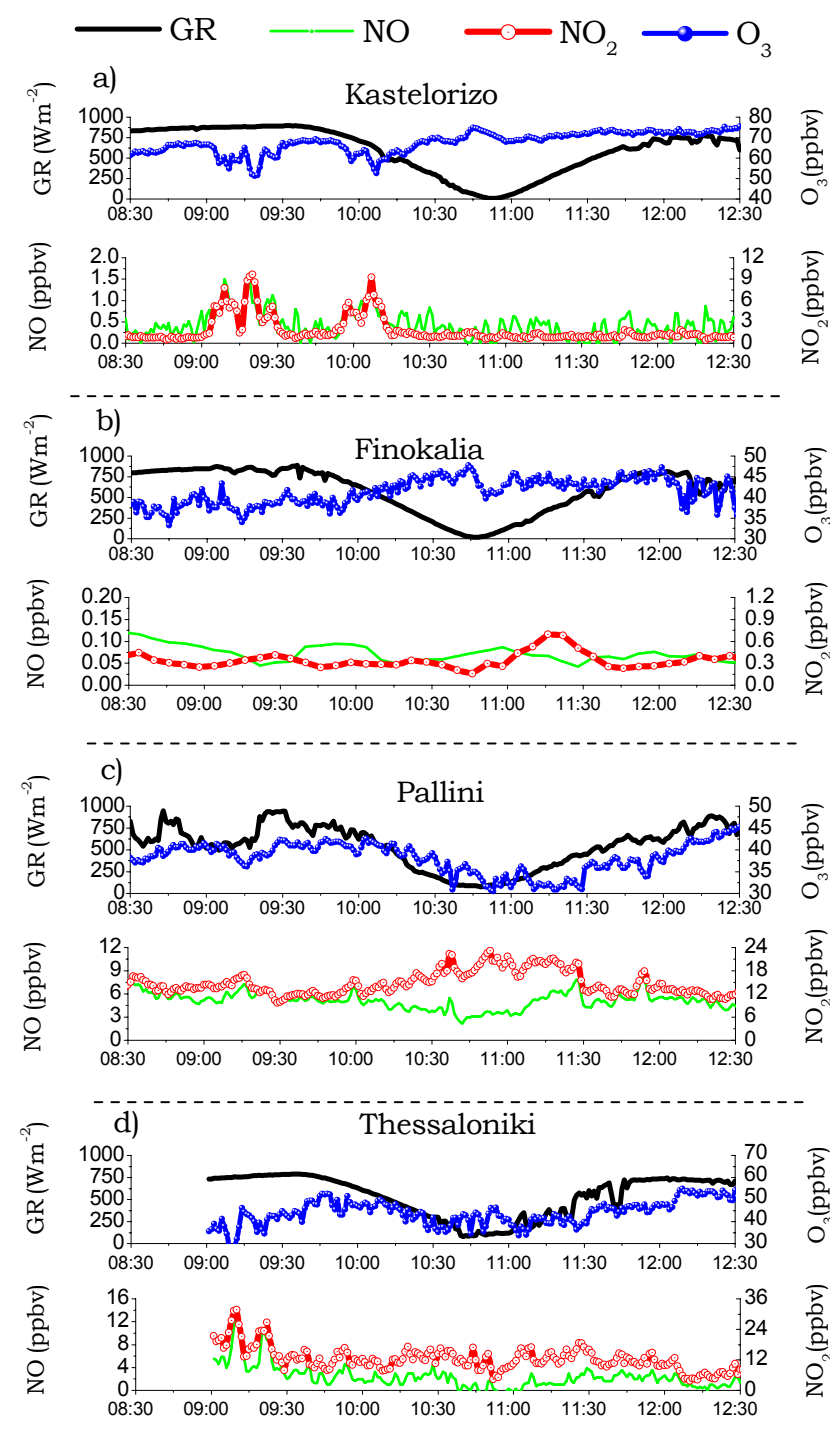

Fig. 1. Time series of $\mathrm{O}_{3}, \mathrm{NO}, \mathrm{NO}_{2}$ and global radiation at Kastelorizo, Finokalia, Pallini and Thessaloniki during the eclipse day of 29 March 2006 from 08:38 to 12:28. Time is expressed in UTC.

builds up during the eclipse. The $\mathrm{O}_{3}, \mathrm{NO}_{2}$ and NO measurements at Thessaloniki show similar behaviour with Pallini but with higher variability. The ozone decline at Thessaloniki during the eclipse is between 5 and 10 ppbv while NO values drop below the detection limit of the instrument during the maximum coverage of the solar disk. The differences in $\mathrm{O}_{3}, \mathrm{NO}_{2}$ and $\mathrm{NO}$ concentrations between their averaged values in the time window of maximum total solar obscuration (10:30-11:00 UTC) and their averaged values from both the time windows before and after the eclipse (09:30 10:00 UTC and 11:30-12:00 UTC) reveal $\mathrm{O}_{3}$ decrease by -8 and -4 ppbv, NO decrease by -1 and -2 ppbv and $\mathrm{NO}_{2}$ increase by 2 , and 6 ppbv for Thessaloniki and Pallini, respectively (see Table 4 ). The average solar obscuration for 
Table 2. Correlation coefficients of observed $\mathrm{O}_{3}, \mathrm{NO}_{2}$ and $\mathrm{NO}$ with observed Global Radiation (GR) over the time window 09:3012:00 UTC when the eclipse took place for the sites Kastelorizo, Finokalia, Pallini and Thessaloniki.

\begin{tabular}{rrrr}
\hline & $\mathrm{O}_{3}$ vs GR & $\mathrm{NO}_{2}$ vs GR & NO vs GR \\
\hline Kastelorizo & -0.27 & 0.27 & 0.21 \\
Finokalia & -0.51 & -0.04 & 0.11 \\
Pallini, Athens & 0.71 & -0.82 & 0.59 \\
Thessaloniki & 0.63 & 0.02 & 0.58 \\
\hline
\end{tabular}

the time window 10:30-11:00 UTC is $\sim 86 \%$ for Kastelorizo, $\sim 82 \%$ for Finokalia, $\sim 76 \%$ for Pallini (Athens) and $\sim 71 \%$ for Thessaloniki.

The similar behaviour of $\mathrm{O}_{3}, \mathrm{NO}_{2}$ and $\mathrm{NO}$ concentrations at the two polluted sites, Pallini and Thessaloniki, can be attributed to perturbation of the photostationary state of $\mathrm{O}_{3}$, $\mathrm{NO}$ and $\mathrm{NO}_{2}$ during the eclipse, with $\mathrm{NO}_{2}$ formed from the reaction of $\mathrm{O}_{3}$ with $\mathrm{NO}$ and not efficiently photolysed. The net effect is a decrease in $\mathrm{O}_{3}$ and $\mathrm{NO}$ while $\mathrm{NO}_{2}$ is accumulated.

The fact that the response of observed $\mathrm{O}_{3}, \mathrm{NO}_{2}$ and $\mathrm{NO}$ to the solar eclipse is mainly indicated at the two polluted sites (Thessaloniki and Pallini) and not at the relatively unpolluted sites (Kastelorizo and Finokalia) is also depicted in Table 2, which presents the correlation coefficients of observed $\mathrm{O}_{3}$, $\mathrm{NO}_{2}$ and $\mathrm{NO}$ with observed global radiation (GR) over the time window 09:30-12:00 UTC when the eclipse took place. Specifically, at the polluted sites we note a positive correlation of $\mathrm{O}_{3}$ and $\mathrm{NO}$ with GR and a negative correlation of $\mathrm{NO}_{2}$ with GR. This can be attributed to the fact that during the evolution of the solar eclipse the decrease of solar radiation is associated with a decrease in $\mathrm{O}_{3}$ and $\mathrm{NO}$ and an increase in $\mathrm{NO}_{2}$ in accordance with theoretical expectations from the perturbation of the photostationary state of $\mathrm{O}_{3}, \mathrm{NO}$ and $\mathrm{NO}_{2}$. The only exception is the lack of correlation between $\mathrm{NO}_{2}$ and GR at Thessaloniki.

In contrast at the two relatively unpolluted sites we note a negative correlation of $\mathrm{O}_{3}$ with GR which means that the decrease of solar radiation during the eclipse is surprisingly associated with an increase in $\mathrm{O}_{3}$. Furthermore we note a lack of statistical significant correlation (at the $95 \%$ confidence level) of $\mathrm{NO}$ and $\mathrm{NO}_{2}$ with GR. These results do not corroborate with our expectations from the perturbation of photostationary state of $\mathrm{O}_{3}, \mathrm{NO}$ and $\mathrm{NO}_{2}$ during the eclipse and point to longer lifetimes of these species and local to regional transport effects masking the eclipse effects.

In order to quantify the magnitude of the solar eclipse effect on these species chemical box modelling and regional air-quality modelling have been used at all four sites as it is discussed in the following Sects. 3.2 and 3.3.

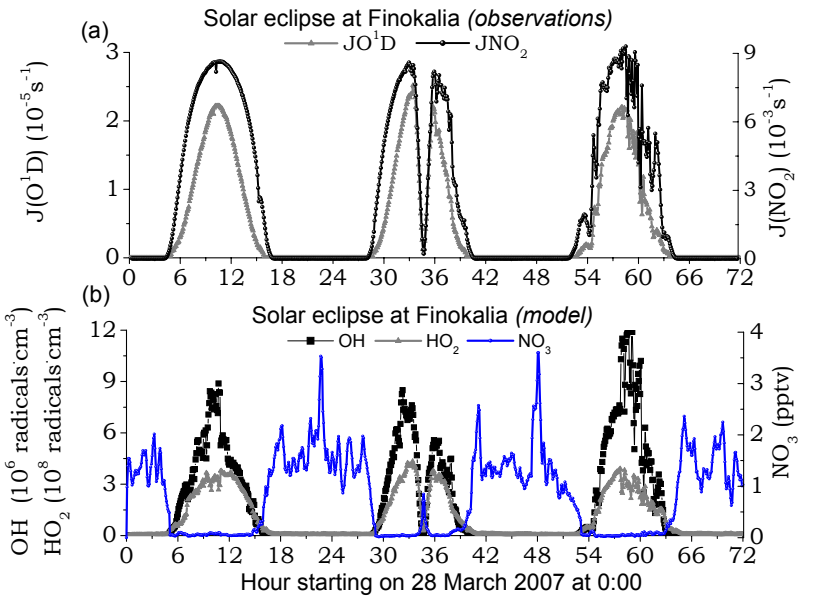

Fig. 2. (a) Measured photolysis rates of $\mathrm{NO}_{2}\left(\mathrm{JNO}_{2}\right)$ and $\mathrm{O}_{3}(\mathrm{JO} 1 \mathrm{D})$ at Finokalia over a 3 days period around the eclipse of the 29th of March 2006. (b) hydroxyl $(\mathrm{OH})$, hydrogen peroxy $\left(\mathrm{HO}_{2}\right)$ and nitrate $\left(\mathrm{NO}_{3}\right)$ radical levels simulated by the chemical box model for Finokalia during these 3 days. Time is expressed in UTC.

\subsection{Box model results}

Driven by the observed $\mathrm{JNO}_{2}$ and $\mathrm{JO}^{1} \mathrm{D}$ variations during the eclipse period (Fig. 2a), the box model simulates a sharp change from daytime to nighttime chemistry as depicted in Fig. $2 b$ for Finokalia station. During the eclipse period hydroxyl $(\mathrm{OH})$ and hydrogen peroxy $\left(\mathrm{HO}_{2}\right)$ radicals, mainly photochemically produced, show rapid decrease by more than an order of magnitude to nighttime levels. Such rapid changes in $\mathrm{OH}$ radical concentrations have been indeed measured by Abram et al. (2000) during the 97\% solar eclipse at Silwood Park, Ascot, UK in August 1999. Simultaneously our model simulations show that nitrate $\left(\mathrm{NO}_{3}\right)$ radical - mainly present during night - is increasing to the pptv level typical of nighttime conditions over the area (Vrekoussis et al., 2006, 2007).

Similar conclusions are drawn from the box model simulations for the other observational sites. This is evident from Table 3, which shows the concentrations of $\mathrm{NO}_{3}, \mathrm{HO}_{2}$ and $\mathrm{OH}$ for eclipse and non-eclipse conditions in box model simulations at the time of maximum solar obscuration for all four sites. Specifically averaged within the window of the eclipse maximum (10:30-11:00 UTC), OH radicals decrease by more than $93 \%$ at all sites while $\mathrm{HO}_{2}$ radicals decrease by about $84 \%$ at Finokalia, $72 \%$ at Kastelorizo, $62 \%$ at Thessaloniki and $58 \%$ at Pallini. Finally the $\mathrm{NO}_{3}$ radicals increase in the window of the maximum solar obscuration and reach around 2 ppbv at Kastelorizo and Thessaloniki, and 0.5 pptv at Finokalia and Pallini. In Table 3 we also note that $\mathrm{HO}_{\mathrm{x}}$ $\left(\mathrm{HO}_{2}+\mathrm{OH}\right)$ levels are lower at the polluted sites than at the relatively unpolluted sites as $\mathrm{HO}_{\mathrm{x}}$ levels are suppressed at high $\mathrm{NO}_{\mathrm{x}}$ conditions. 
Table 3. Concentrations of $\mathrm{NO}_{3}, \mathrm{HO}_{2}$ and $\mathrm{OH}$ for eclipse and non-eclipse conditions in box model simulations at the window of maximum solar obscuration (10:30-11:00 UTC) for the sites Kastelorizo, Finokalia, Pallini and Thessaloniki.

\begin{tabular}{lllllll}
\hline & $\mathrm{NO}_{3}(\mathrm{pptv})$ & $\mathrm{HO}_{2}\left(10^{6} \mathrm{molec}^{\cdot} \mathrm{cm}^{-3}\right)$ & $\mathrm{OH}\left(10^{4} \mathrm{molec}^{\cdot} \mathrm{cm}^{-3}\right)$ \\
\hline & Eclipse & $\begin{array}{l}\text { No } \\
\text { Eclipse }\end{array}$ & Eclipse & No & Eclipse & No \\
Kastelorizo & 1.67 & 0.15 & 80.1 & 285.6 & 22.4 & Eclipse \\
Finokalia & 0.50 & 0.04 & 66.1 & 404.0 & 40.5 & 592.5 \\
Palini & 0.47 & 0.07 & 1.3 & 3.1 & 8.9 & 135 \\
Thessaloniki & 1.92 & 0.28 & 2.2 & 5.8 & 2.9 & 51.8 \\
\hline
\end{tabular}

According to our box model simulations for Kastelorizo, during day, outside the eclipse period, $\mathrm{OH}$ radicals are 40 times and almost 3 orders of magnitude more effective than $\mathrm{NO}_{3}$ radicals in oxidizing DMS and isoprene, respectively. During the eclipse this pattern is reversed and $\mathrm{NO}_{3}$ radicals are the most efficient oxidant being 70 times and 4 orders of magnitude more efficient than $\mathrm{OH}$ in oxidizing DMS and isoprene, respectively.

This drastic and sudden change from daytime to nighttime chemistry during the eclipse has also markedly affected the modelled $\mathrm{O}_{3}$ budget changes simulated by the chemical box model for Finokalia (location with 95.6\% coverage). Indeed, comparing simulations both by considering and by neglecting the perturbation of photodissociation rates due to the solar eclipse, it was calculated a mean decrease in the net ozone production rate $\left(\mathrm{NetPO}_{3}=\mathrm{PO}_{3}-\mathrm{QO}_{3}\right)$ of $1.20 \mathrm{ppbv} / \mathrm{h}$ (see Table 5) when integrated over the eclipse period (09:3012:00; Fig. $3 \mathrm{~b})$. The $\mathrm{O}_{3}$ production term $\left(\mathrm{PO}_{3}\right)$ was calculated by the photolysis of $\mathrm{NO}_{2}$ to $\mathrm{NO}$ after substracting the titration of $\mathrm{O}_{3}$ by $\mathrm{NO}$ while the $\mathrm{O}_{3}$ loss term $\left(\mathrm{QO}_{3}\right)$ was derived from the rate of the $\mathrm{O}^{1} \mathrm{D}$ reaction with $\mathrm{H}_{2} \mathrm{O}$ and of $\mathrm{O}_{3}$ reactions with $\mathrm{HO}_{\mathrm{x}}$ and with unsaturated hydrocarbons. A slightly higher change in $\mathrm{NetPO}_{3}$ of $-1.83 \mathrm{ppbv} / \mathrm{h}$ was calculated by the box model for Kastelorizo (location with almost $100 \%$ coverage) averaged between the time window 09:30 and 12:00 UTC (see Table 5). Even higher changes in NetPO3 averaged between 09:30 and 12:00 UTC have been computed for Thessaloniki $(7.65 \mathrm{ppbv} / \mathrm{h})$ that is an urban location with smaller eclipse coverage whereas the highest changes have been computed for Pallini (38.33 ppbv/h) that experiences the highest NO levels among the studied sites. Note that these budget calculations do account for the titration of $\mathrm{O}_{3}$ by $\mathrm{NO}$ that significantly affects $\mathrm{O}_{3}$ levels in polluted regions, like Thessaloniki and Pallini. In parallel $\mathrm{NO}_{2}$ increases due to the absence of $\mathrm{NO}_{2}$ photodissociation as indicated by the observed almost zero $\mathrm{JNO}_{2}$ values.

\subsection{Regional air quality model results}

As described in Sect. 2.3 CAMx calculated the diurnal variation of the photolysis rate $\mathrm{JNO}_{2}$ for eclipse and non-eclipse

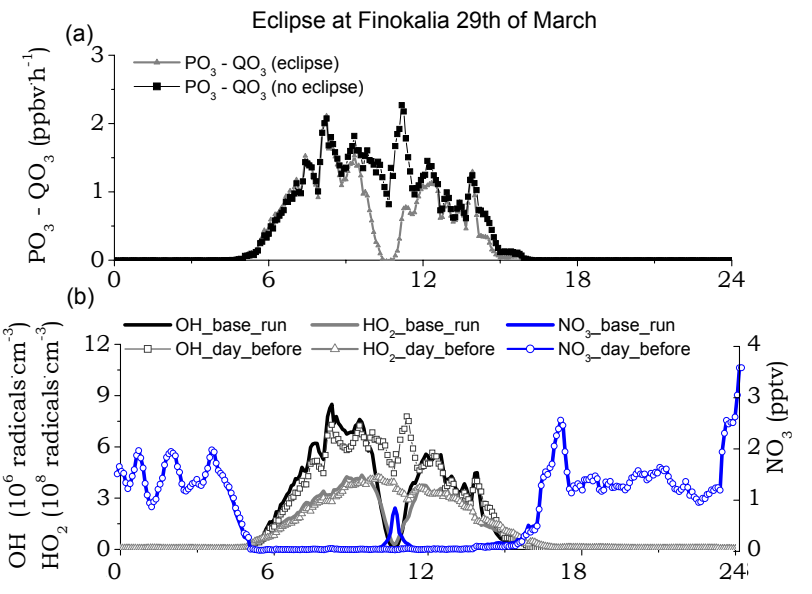

Fig. 3. (a) Net $\mathrm{O}_{3}$ chemical production $\left(\mathrm{NetPO}_{3}=\mathrm{PO}_{3}-\mathrm{QO}_{3}\right)$ at Finokalia during the day of the eclipse, 29th of March 2006, simulated by considering the effect of eclipse of photolysis rates (NetPO3_base-run) and by neglecting it (NetPO3_jdaybefore) (b) as (a) but for $\mathrm{OH}, \mathrm{HO}_{2}$ and $\mathrm{NO}_{3}$ radical levels. Time is expressed in UTC. $\mathrm{NetPO}_{3}=\mathrm{PO}_{3}-\mathrm{QO}_{3}$, where $\mathrm{PO}_{3}=\Sigma \mathrm{R}_{\mathrm{RO}} \mathrm{NO} \mathrm{NO}$, $\mathrm{QO}_{3}=\mathrm{O}^{1} \mathrm{D}+\mathrm{H}_{2} \mathrm{O}$, alkenes $+\mathrm{O}_{3}$

conditions. An example for these calculations is shown in Fig. 4. $\mathrm{NO}_{2}$ photolysis rates (black curve) follow a sinusoidal curve increasing gradually after 04:00 UTC and returning to almost zero values after around 16:30 UTC. When considering the eclipse in the calculations (magenta curve), the modelled $\mathrm{NO}_{2}$ photolysis rates gradually decrease after 09:30 UTC to minimize at around 11:00 UTC and one hour later return to the non-eclipse values. It should be noted the good level of agreement at Finokalia between the modelled $\mathrm{JNO}_{2}$ values and the observed $\mathrm{JNO}_{2}$ values (Fig. 4b). The maximum of the observed $\mathrm{JNO}_{2}$ values is around $8.1 \times 10^{-3} \mathrm{~s}^{-1}$ while the respective value calculated in CAMx is $7.6 \times 10^{-3} \mathrm{~s}^{-1}$. The relative reduction of photolysis rates is space dependent according to the distance from the centre of the eclipse shadow. In order to depict the impact of eclipse on $\mathrm{JNO}_{2}$ over the whole modelling region, the percentage of $\mathrm{JNO}_{2}$ relative decrease $\left(\mathrm{JNO}_{2 \mathrm{ecl}}-\mathrm{JNO}_{2 o}\right) / \mathrm{JNO}_{2 o}$ 

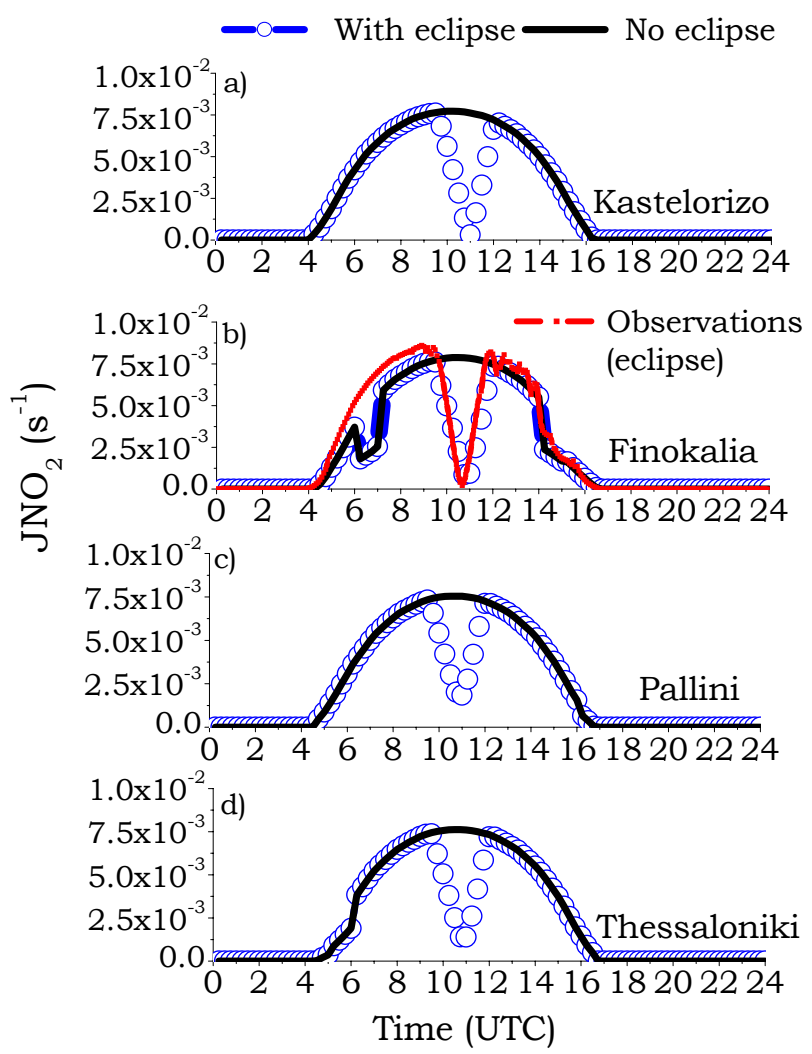

Fig. 4. Diurnal variation of the photolysis rate constant $\mathrm{J}\left(\mathrm{NO}_{2}\right)$ values calculated in CAMx simulations for eclipse and non-eclipse conditions at Kastelorizo, Finokalia, Pallini and Thessaloniki. The observed $\mathrm{J}\left(\mathrm{NO}_{2}\right)$ values for Finokalia are also indicated.

was plotted over the master domain (here subscript "o" denoting simulations without eclipse and "ecl" simulation with eclipse) averaged for the time window 10:00-11:00 UTC (Fig. 5). A decrease in $\mathrm{JNO}_{2}$ of $60-65 \%$ was calculated for Kastelorizo and 55-60\% for Finokalia, 45-50 \% for Pallini (Athens) and 40-45\% for the Thessaloniki.

The values of $\mathrm{O}_{3}, \mathrm{NO}_{2}$ and $\mathrm{NO}$ simulated by CAMx and averaged over the time window 09:30-12:00 UTC when the eclipse took place for the four different sites are also shown in Table 1 for comparison with observations. Furthermore in order to have a measure of the model performance the mean bias between modelled and observed values was calculated from the formula $(1 / \mathrm{N}) \sum\left(\bmod _{i}-\mathrm{obs}_{i}\right)$ for the time window 09:30-12:00 UTC. From the calculation of the mean bias is clearly evident that the model simulation for $\mathrm{O}_{3}$ at Kastelorizo presents the largest uncertainty with a mean bias of $16 \mathrm{ppbv}$ while for $\mathrm{NO}_{\mathrm{x}}$ we have the largest percentage uncertainty.

Comparing the simulations with the observations the following remarks can be made:

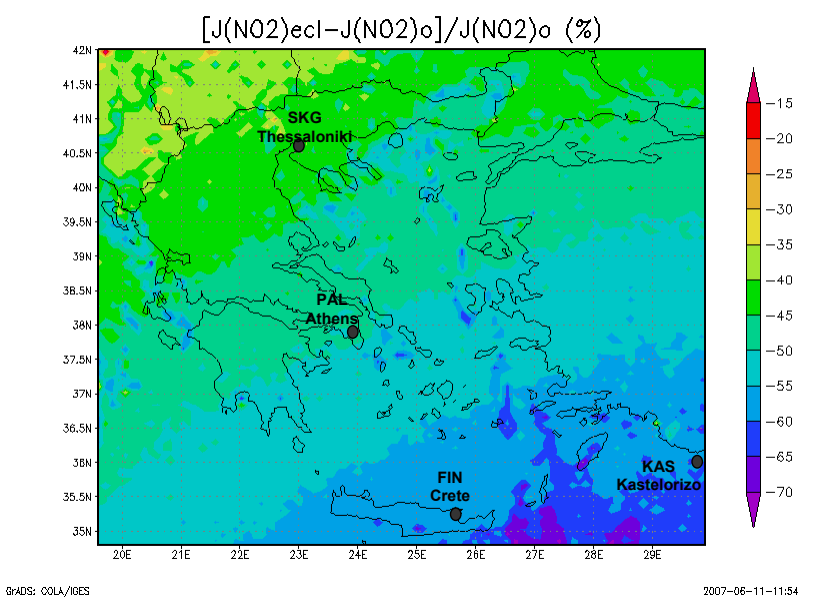

Fig. 5. Percentage decrease of $\mathrm{NO}_{2}$ photolysis rates averaged for the time window 10:00-11:00 UTC over the master modeling domain. The four dots show the four observational sites.

1. The simulated $\mathrm{O}_{3}$ at Kastelorizo is significantly lower than the observations. Similarly the simulated $\mathrm{NO}_{\mathrm{x}}$ levels are underestimated compared to the observations, possibly due to generally underestimated anthropogenic emissions over Turkey, which lies only a few kilometers away from Kastelorizo and/or to the clean-atmosphere boundaries that was assumed for this run: Kastelorizo is the easternmost Greek island close to the edges of our domain.

2. At Finokalia both the simulated $\mathrm{O}_{3}$ and $\mathrm{NO}_{\mathrm{x}}$ values agree with the observations.

3. The modelled $\mathrm{O}_{3}, \mathrm{NO}_{2}$ and $\mathrm{NO}$ values at Pallini and Thessaloniki compare rather well with the respective observations.

4. Both the observed and modelled $\mathrm{O}_{3}$ levels at Pallini are lower than at Thessaloniki by a few ppbv whereas both the observed and modelled $\mathrm{NO}_{\mathrm{x}}$ levels at Pallini are slightly higher than at Thessaloniki. This pattern is coherent with the non-linear behaviour in $\mathrm{O}_{3}$ production that associates an increase in $\mathrm{NO}_{\mathrm{x}}$ in these highly polluted sites with a suppression of $\mathrm{O}_{3}$ production.

The average differences of $\mathrm{O}_{3}, \mathrm{NO}_{2}$ and $\mathrm{NO}$ between eclipse and non-eclipse conditions in CAMx simulations over the time window of the eclipse (09:30-12:00 UTC) and for maximum coverage of the sun-disk for the four sites are indicated in Table 4. At the relatively unpolluted sites of Kastelorizo and Finokalia, the CAMx simulations indicate an ozone decrease of only $-0.4 \mathrm{ppbv}$ for Kastelorizo and $-1.0 \mathrm{ppbv}$ for Finokalia at the time of the maximum coverage of the sun-disk. These values are smaller than the standard deviation of the ozone measurements during the time 
Table 4. Differences of $\mathrm{O}_{3}, \mathrm{NO}_{2}$ and $\mathrm{NO}$ between eclipse and non-eclipse conditions in $\mathrm{CAMx}$ simulations over the time window of the eclipse 09:30-12:00 UTC for the sites Kastelorizo, Finokalia, Pallini and Thessaloniki. The values in parentheses correspond to the respective values of differences for the maximum sun coverage. The differences from the observations of $\mathrm{O}_{3}, \mathrm{NO}_{2}$ and $\mathrm{NO}_{\text {between their }}$ averaged values in the time window of maximum total solar obscuration 10:30-11:00 UTC and their averaged values from both the time windows before and after the eclipse (09:30-10:00 UTC and 11:30-12:00 UTC) are also provided for comparison.

\begin{tabular}{llrlrlr}
\hline & $\begin{array}{l}\Delta \mathrm{O}_{3}(\mathrm{ppbv}) \\
\text { Model }\end{array}$ & Obs & $\begin{array}{l}\Delta \mathrm{NO}_{2}(\mathrm{ppbv}) \\
\text { Model }\end{array}$ & Obs & $\begin{array}{l}\Delta \mathrm{NO}(\mathrm{ppbv}) \\
\text { Model }\end{array}$ & Obs \\
\hline Kastelorizo & $-0.3(-0.4)$ & 0.8 & $0.03(0.06)$ & -0.35 & $-0.01(-0.03)$ & -0.06 \\
Finokalia & $-0.7(-1.0)$ & 2.3 & $0.06(0.11)$ & -0.07 & $-0.02(-0.05)$ & 0.00 \\
Pallini, Athens & $-4.1(-6.4)$ & -4.0 & $3.41(5.75)$ & 5.56 & $-2.35(-4.99)$ & -2.10 \\
Thessaloniki & $-5.8(-10.6)$ & -8.4 & $3.44(7.3)$ & 1.84 & $-0.19(-1.25)$ & -0.93 \\
\hline
\end{tabular}

window of the eclipse for both sites (see Table 1). Specifically the standard deviation of the ozone measurements for the time window 09:30-12:00 UTC is $4.3 \mathrm{ppbv}$ at Kastelorizo and $2.5 \mathrm{ppbv}$ at Finokalia. Hence comparing the simulated from CAMx eclipse effect on ozone with the short-term observed ozone variability it is easily conceived why a clear evidence of the solar eclipse on $\mathrm{O}_{3}$ cannot be supported for both Kastelorizo and Finokalia (Fig. 1). Similarly the CAMx simulations indicate only small changes for $\mathrm{NO}$ and $\mathrm{NO}_{2}$ for Kastelorizo and Finokalia during the solar eclipse. In particular, increases in $\mathrm{NO}_{2}$ of 0.06 and $0.11 \mathrm{ppbv}$ and decreases in NO of 0.03 and $0.05 \mathrm{ppbv}$ have been calculated at the time of the maximum coverage of sun-disk for Kastelorizo and Finokalia, respectively. It should be further noted from Table 4 that the differences from the observations of $\mathrm{O}_{3}, \mathrm{NO}_{2}$ and $\mathrm{NO}$ between their averaged values in the time window of maximum total solar obscuration (10:30-11:00 UTC) and their averaged values from both the time windows before and after the eclipse (09:30-10:00 UTC and 11:30-12:00 UTC) are generally not consistent with the CAMx calculations of the eclipse effects on these species. This inconsistency points to the fact that at these relatively unpolluted sites the eclipse effects on the observations of $\mathrm{O}_{3}, \mathrm{NO}_{2}$ and $\mathrm{NO}$ are masked.

Mind also that the changes in $\mathrm{O}_{3}, \mathrm{NO}_{2}$ and $\mathrm{NO}$ between eclipse and non-eclipse conditions in the CAMx simulations for Kastelorizo are smaller than for Finokalia even though at Kastelorizo there was almost $100 \%$ sun coverage. This discrepancy can be attributed to the lower pollution levels at Kastelorizo in CAMx runs. Hence we anticipate that the CAMx simulations of the changes in $\mathrm{O}_{3}, \mathrm{NO}_{2}$ and $\mathrm{NO}$ between eclipse and non-eclipse conditions for Kastelorizo are underestimated because of the underestimation of $\mathrm{O}_{3}$ and NOx levels in the CAMx results compared to observations (see Tables 1 and 2), earlier discussed.

At the polluted sites the CAMx simulations indicate an ozone decrease of $6.4 \mathrm{ppbv}$ for Pallini and $10.6 \mathrm{ppbv}$ for Thessaloniki at the time of the maximum coverage of the sun-disk. The CAMx simulated $\mathrm{O}_{3}$ change between eclipse and non-eclipse conditions integrated over the time window of the eclipse 09:30-12:00 UTC is $-4.1 \mathrm{ppbv}$ for Pallini and $-5.8 \mathrm{ppbv}$ for Thessaloniki (see also Table 4). These simulated ozone decreases due to the solar eclipse are in good agreement with the in-situ ozone observations at the two polluted sites (see Table 4). For example, the difference in the observed $\mathrm{O}_{3}$ between the averaged value in the time window of maximum total solar obscuration (10:30-11:00 UTC) and the averaged values from both the time windows before and after the eclipse (09:30-10:00 UTC and 11:30-12:00 UTC) is -8 and -4 ppbv for Thessaloniki and Pallini, respectively.

Furthermore, CAMx simulations indicate a decrease in $\mathrm{NO}$ of $-2.55 \mathrm{ppbv}$ and an increase in $\mathrm{NO}_{2}$ of $3.41 \mathrm{ppbv}$ for Pallini over the time window of the eclipse 09:3012:00 UTC. The observations of $\mathrm{NO}$ and $\mathrm{NO}_{2}$ at Pallini taking the difference between the time window of the maximum coverage of the sun disk and the time windows before and after the completion of the solar eclipse indicate a $\mathrm{NO}$ decrease of $-2.1 \mathrm{ppbv}$ and $\mathrm{NO}_{2}$ increase of $5.6 \mathrm{ppbv}$. The CAMx simulations at Thessaloniki indicate a decrease in $\mathrm{NO}$ of $-0.19 \mathrm{ppbv}$ and an increase in $\mathrm{NO}_{2}$ of $3.44 \mathrm{ppbv}$ over the time window of the eclipse 09:30-12:00 UTC whereas the observations indicate NO decrease of about $-1 \mathrm{ppbv}$ and $\mathrm{NO}_{2}$ increase of about 2 ppbv. Hence the CAMx simulated values of the differences of $\mathrm{O}_{3}, \mathrm{NO}_{2}$ and $\mathrm{NO}$ between eclipse and non-eclipse conditions compare reasonably well with observations for both Pallini and Thessaloniki.

The lifetime of any chemical species in equilibrium can be defined by the concentration of this chemical species divided with its destruction or production rate. In the background atmosphere the ozone gas phase destruction rate is basically determined from fractional ozone photolysis in reactions (R4) and (R5) as well as reactions of ozone with $\mathrm{HO}_{\mathrm{x}}\left(\mathrm{HO}_{2}+\mathrm{OH}\right)$ radicals in reactions (R8) and (R9). The chemical process analysis in CAMx calculates the ozone destruction rate due to the above mentioned processes and other ozone destruction pathways including ozone titration by NO and ozone reaction with alkenes. We calculated the ozone lifetime based on CAMx simulated fields for the four sites for both the eclipse and non-eclipse conditions. For the two 
Table 5. Net $\mathrm{O}_{3}$ chemical production $\left(\mathrm{NetPO}_{3}=\mathrm{PO}_{3}-\mathrm{QO}_{3}\right)$ at the four studied sites for eclipse and non-eclipse conditions over the time window of eclipse 09:30-12:00 UTC in CAMx and Box Model as well as their difference $\Delta \mathrm{NetPO}_{3}$ between eclipse and noneclipse conditions.

\begin{tabular}{rrrl}
\hline & $\begin{array}{r}\mathrm{NetPO}_{3} \\
\text { eclipse } \\
(\mathrm{ppbv} / \mathrm{h})\end{array}$ & $\begin{array}{r}\mathrm{NetPO}_{3} \\
\text { non-eclipse } \\
(\mathrm{ppbv} / \mathrm{h})\end{array}$ & $\begin{array}{l}\Delta \mathrm{NetPO}_{3} \\
(\mathrm{ppbv} / \mathrm{h})\end{array}$ \\
\hline $\begin{array}{r}\text { Kastelorizo } \\
\text { CAMx }\end{array}$ & 0.17 & 0.33 & -0.16 \\
Box Model & -0.09 & 1.74 & -1.83 \\
Finokalia & & & \\
CAMx & 0.72 & 1.32 & -0.60 \\
Box Model & 0.17 & 1.48 & -1.20 \\
Palini & & & \\
CAMx & -7.24 & -3.53 & -3.71 \\
Box Model & -8.53 & 29.8 & -38.33 \\
Thessaloniki & & & \\
CAMx & -40.65 & -31.53 & -9.12 \\
Box Model & -11.93 & -4.28 & -7.65 \\
\hline
\end{tabular}

relatively unpolluted sites, Kastelorizo and Finokalia, the ozone lifetime is about 2.7 days for non-eclipse conditions and becomes around 6.5 days for eclipse conditions. The first point to be mentioned is that for such ozone lifetimes it is sensible that we do not clearly see an abrupt and major signal of solar eclipse on surface $\mathrm{O}_{3}$ as in this timescale local to regional scale transport effects may mask the eclipse effects. The second point to be noted is that the ozone lifetime increases as we move from non-eclipse to eclipse conditions which can be explained by the fact that in the relatively unpolluted atmosphere (far from high $\mathrm{NO}_{\mathrm{x}}$ emission areas) the ozone loss terms are reduced during the eclipse as both $\mathrm{HO}_{\mathrm{x}}$ and $\mathrm{JO}^{1} \mathrm{D}$ levels are reduced. For the polluted sites, Thessaloniki and Pallini, the ozone lifetimes are much smaller being $1.3 \mathrm{~h}$ and $3 \mathrm{~h}$ for eclipse conditions and $1.9 \mathrm{~h}$ and $7.8 \mathrm{~h}$ for non-eclipse conditions, respectively, which can be explained by the fact that in high $\mathrm{NO}_{\mathrm{x}}$ emission areas there is rapid ozone destruction by NO-titration dominating over the other ozone loss terms (CAMx version 4.40, 2006). In contrast to the relatively unpolluted sites, at the two polluted sites we note that the ozone lifetime decreases as we move from noneclipse to eclipse conditions. This can be attributed to the fact that ozone during the eclipse continues to be removed by its reaction with NO (R3) without being efficiently reproduced by $\mathrm{NO}_{2}$ photolysis in reaction $(\mathrm{R} 1)$.

The eclipse effect over Greece as calculated by CAMx is depicted in Fig. 6 that shows the differences in $\mathrm{NO}_{2}, \mathrm{NO}$ and $\mathrm{O}_{3}$ between eclipse and non-eclipse conditions for the first model level $\mathrm{Z} 1(<22 \mathrm{~m})$ averaged over the time window 10:00-11:00 UTC. Over Greece the maximum impacts of the eclipse on $\mathrm{O}_{3}, \mathrm{NO}_{2}$ and $\mathrm{NO}$ are calculated to occur over the large urban agglomerations of Athens, and Thessaloniki where the maximum of the emissions occur. Furthermore, we note a stripe at the western Aegean Sea with notable eclipse effects on these air pollutants which might be associated to ship emissions since ship trails coincide in space.

Comparing the net $\mathrm{O}_{3}$ production calculated by the box model and by the regional air-quality model (see Table 5) we note a relatively good agreement at Finokalia and Thessaloniki for the difference $\triangle \mathrm{NetPO}_{3}$ (between $\mathrm{NetPO}_{3}$ for eclipse and $\mathrm{NetPO}_{3}$ for non-eclipse conditions) when integrated over the eclipse window. At Pallini and Kastelorizo we also note a rather good comparison between CAMx and box model calculations for $\mathrm{NetPO}_{3}$ for eclipse conditions $(0.17 \mathrm{ppbv} / \mathrm{h}$ in CAMx versus $-0.09 \mathrm{ppbv} / \mathrm{h}$ in box model for Kastelorizo and $-7.24 \mathrm{ppbv} / \mathrm{h}$ in CAMx versus $-8.53 \mathrm{ppbv} / \mathrm{h}$ in box model for Pallini). However the $\mathrm{NetPO}_{3}$ for non-eclipse conditions in box model calculations is higher than in CAMx calculations which is also reflected in the comparison of $\Delta \mathrm{NetPO}_{3}(-0.16 \mathrm{ppbv} / \mathrm{h}$ in CAMx versus $-1.83 \mathrm{ppbv} / \mathrm{h}$ in box model for Kastelorizo and $-3.71 \mathrm{ppbv} / \mathrm{h}$ in CAMx versus $-38.33 \mathrm{ppbv} / \mathrm{h}$ in box model for Pallini). Indeed the box model calculations overestimate the impact of the eclipse on $\mathrm{NetPO}_{3}$ at Kastelorizo and Pallini in comparison with CAMx calculations but at least they have similar sign. For the case of Kastelorizo, as earlier discussed this underestimation in CAMx compared to box model could be attributed to generally underestimated anthropogenic emissions over Turkey and/or to cleanatmosphere boundaries conditions assumed for the CAMx run at the edge of our domain where the Kastelorizo is located. Furthermore it should be kept in mind that differences between CAMx and box model calculations for the eclipse effect may also rise from the fact that the box model evaluates the in-situ effect of eclipse on $\mathrm{O}_{3}$ production resulting from the photolysis rates changes alone whereas the regional model in addition accounts for air masses mixing due to transport.

\section{Summary and conclusions}

The present work investigated the chemical effects of the solar eclipse of 29 March 2006 on surface air quality levels over Greece based on observations at a number of sites in conjunction with chemical box modelling and 3-D air-quality modelling. Emphasis has been given on surface ozone and other photooxidants at four Greek sites Kastelorizo, Finokalia (Crete), Pallini (Athens) and Thessaloniki, which are located at gradually increasing distances from the eclipse path and are characterized by different air pollution levels. The different solar obscuration at each site combined with a variety of environments, by means of air quality level, namely polluted urban/suburban (Thessaloniki, Pallini), and relatively unpolluted coastal (Finokalia, Kastelorizo) enabled 

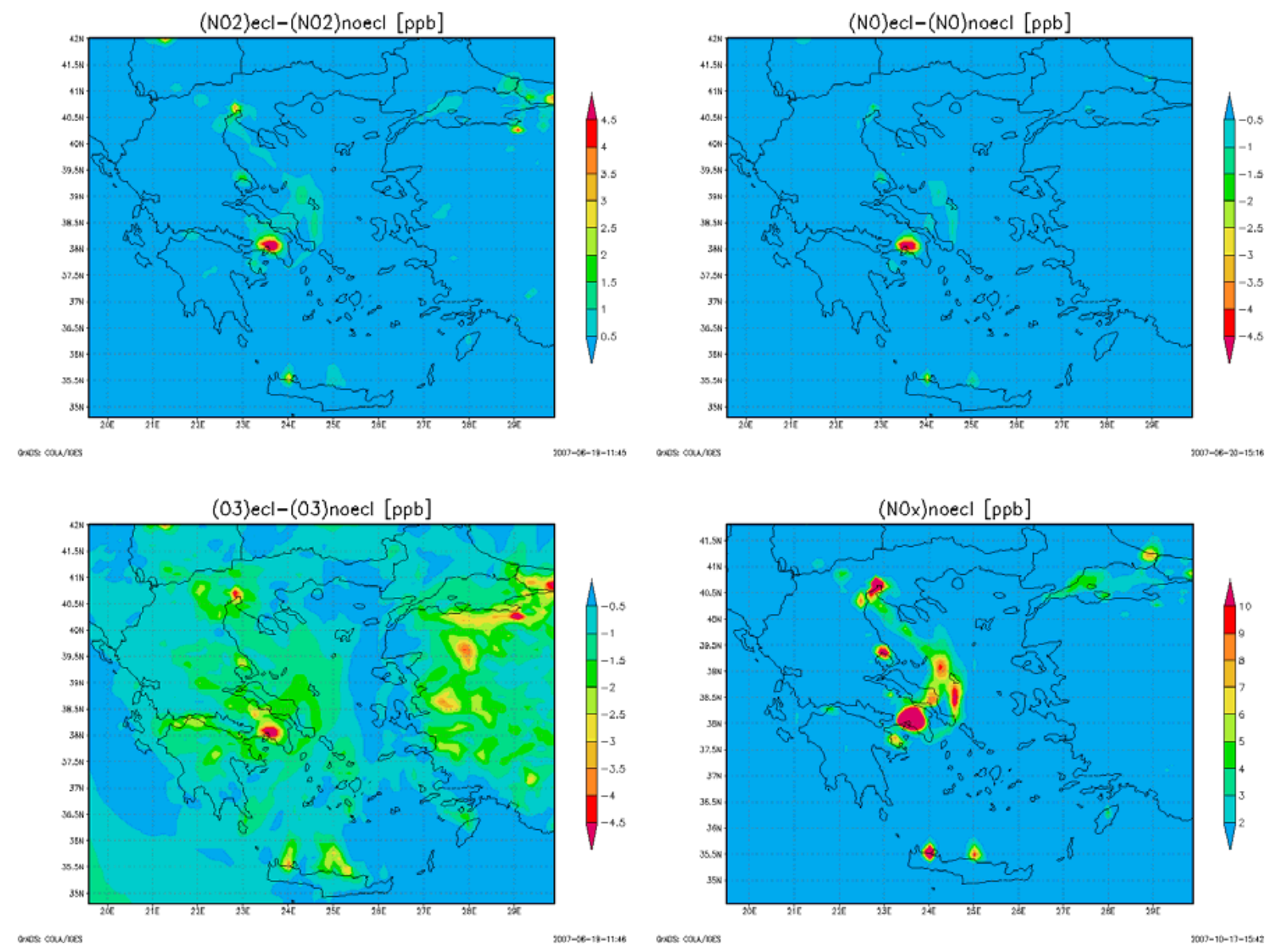

Fig. 6. Differences of $\mathrm{NO}_{2}, \mathrm{NO}$ and $\mathrm{O}_{3}$ between eclipse and non-eclipse conditions in CAMx simulations over the master modeling domain for the first model level Z1 ( $<22 \mathrm{~m})$ averaged for the time window 10:00-11:00 UTC. The NOx concentrations for the non-eclipse simulation is also illustrated to indicate the areas with high levels of pollution.

a thorough investigation of the response of photochemistry to an abrupt photolytical change.

At the relatively unpolluted sites of Kastelorizo and Finokalia no clear impact of solar eclipse on surface $\mathrm{O}_{3}, \mathrm{NO}_{2}$ and $\mathrm{NO}$ concentrations can be deduced from the observations and model simulations. The observations corroborate with chemical box modelling and 3-D air-quality modelling. $\mathrm{O}_{3}$ at Finokalia has been associated with a mean decrease in the net ozone production rate of $1.20 \mathrm{ppbv} / \mathrm{h}$ (box model) and $0.60 \mathrm{ppbv} / \mathrm{h}$ (CAMx) when integrated over the eclipse period (09:30-12:00 UTC). Similarly, at Kastelorizo (location with almost $100 \%$ coverage) $\mathrm{O}_{3}$ has been associated with a mean decrease in the net ozone production rate of $1.83 \mathrm{ppbv} / \mathrm{h}$ (box model) and $0.16 \mathrm{ppbv} / \mathrm{h}$ (CAMx). Such changes in the net ozone production between eclipse and non eclipse conditions, as calculated by both box and 3-D air quality models, are rather small compared to the short-term ozone variability. Furthermore the ozone lifetime is in the range of a few days at these sites and hence the solar eclipse effects on ozone can be easily masked by local and regional transport.

At the polluted urban and suburban sites of Thessaloniki and Pallini, respectively, solar eclipse effects on $\mathrm{O}_{3}, \mathrm{NO}_{2}$ and NO concentrations are clearly indicated from both the measurements and 3-D air-quality modelling. The net effect is a decrease in $\mathrm{O}_{3}$ and $\mathrm{NO}$ while $\mathrm{NO}_{2}$ is accumulated. The common behaviour of $\mathrm{O}_{3}, \mathrm{NO}_{2}$ and $\mathrm{NO}$ concentrations at the two polluted sites, Pallini and Thessaloniki, can be attributed to their perturbation from the photostationary state of $\mathrm{O}_{3}, \mathrm{NO}$ and $\mathrm{NO}_{2}$ during the eclipse, with $\mathrm{NO}_{2}$ formed from the reaction of $\mathrm{O}_{3}$ with $\mathrm{NO}$ while at the same time $\mathrm{NO}_{2}$ is not efficiently photolysed.

The fact that the response of observed $\mathrm{O}_{3}, \mathrm{NO}_{2}$ and $\mathrm{NO}$ to the solar eclipse is mainly indicated at the two polluted sites (Thessaloniki and Pallini) and not at the relatively unpolluted sites (Kastelorizo and Finokalia) is also depicted from the correlation coefficients of observed $\mathrm{O}_{3}, \mathrm{NO}_{2}$ and $\mathrm{NO}$ with 
observed GR. Specifically, at the polluted sites we note a positive correlation of $\mathrm{O}_{3}$ and $\mathrm{NO}$ with GR and a negative correlation of $\mathrm{NO}_{2}$ with GR in accordance with a perturbation of the photostationary state of $\mathrm{O}_{3}, \mathrm{NO}$ and $\mathrm{NO}_{2}$. In contrast at the two relatively unpolluted sites we note a negative correlation of $\mathrm{O}_{3}$ with GR and a lack of correlation of $\mathrm{NO}$ and $\mathrm{NO}_{2}$ with GR.

Box model calculations also demonstrated the rapid decrease of the photochemically produced $\mathrm{OH}$ and $\mathrm{HO}_{2}$ radicals to nighttime levels at all four sites during the eclipse period. Simultaneously the $\mathrm{NO}_{3}$ radical concentration, which is the main nighttime oxidant species, increased at all sites to the pptv level reaching even 4 pptv at Kastelorizo.

The 3-D air quality modelling over Greece simulates the maximum effects of the eclipse on $\mathrm{O}_{3}, \mathrm{NO}_{2}$ and $\mathrm{NO}$ at the large urban agglomerations of Athens, and Thessaloniki where the maximum of the emissions occur.

The net $\mathrm{O}_{3}$ production $\left(\mathrm{NetPO}_{3}\right)$ and the impact of changing photolysis rates on it $\left(\Delta \mathrm{NetPO}_{3}\right)$ calculated by the box model and by the regional air-quality model agree reasonably well when integrated over the eclipse window at Finokalia but is underestimated by CAMx for Kastelorizo. This underestimation is linked to an underestimation of CAMx $\mathrm{O}_{3}$, and $\mathrm{NO}_{\mathrm{x}}$ levels which could be in turn due to generally underestimated anthropogenic emissions over Turkey and/or the fact that Kastelorizo is close to the edge of our domain with clean-atmosphere boundaries conditions assumed for the CAMx run.

Acknowledgements. Compilation and presentation of this work has been facilitated by the ACCENT -EU network of excellence. Support by a research and education PYTHAGORAS II grant co-funded by the Greek Ministry of Education (25\%) and the European Social Fund (75\%) is acknowledged. The air quality and meteorological data of Pallini, Athens were kindly provided by the Air Quality Monitoring Network of Athens International Airport (AIA) Eleftherios Venizelos.

Edited by: P. Monks

\section{References}

Abram, J. P., Creasey, D. J., Dwaye, E. H., Lee, J. D., and Pilling, M. J.: Hydroxyl radical and ozone measurements in England during the solar eclipse of 11 August 1999, Geophys. Res. Lett., 27, 3437-3440, 2000.

CAMx User's Guide, Version 4.40: ENVIRON International Corporation, September 2006, www.camx.com, 2006.

Curtis, A. R. and Sweetenham, W. P: FACSIMILE/CHEKMAT User's Manual AERE R-12805, United Kingdom Atomic Energy Authority (UKAEA), Harwell, 1988.

Dodge, M.: Chemical oxidant mechanisms for air quality modeling: critical review, Atmos. Environ., 34, 2103-2130, 2000.

Gerasopoulos, E., Kouvarakis, G., Vrekoussis, M., Kanakidou, M., and Mihalopoulos, N.: Ozone variability in the marine boundary layer of the eastern Mediterranean based on 7-year observations, J. Geophys. Res., doi:10.1029/2005JD005991, 110 (D15), 2005.

Gerasopoulos, E., Kouvarakis, G., Vrekoussis, M., Donoussis, C., Mihalopoulos, M., and Kanakidou, M.: Photochemical ozone production in the Eastern Mediterranean, Atmos. Environ., 40, 3057-3069, 2006.

Gerasopoulos, E., Zerefos, C. S., Tsagouri, I., et al.: The Total Solar Eclipse of March 2006: Overview, Atmos. Chem. Phys. Discuss., in press, 2007.

Fabian, P., Rappenglueck, B., Stohl, A., Werner, H., Winterhalter, M., Schlager, H., Stock, P., Berresheim, H., Kaminski, U., Koepke, P., Reuder, J., and Birmili, W.: Boundary layer photochemistry during a total solar eclipse, Meteorol. Z., 10 (3), 187192, 2001.

Founda, D., Melas, D., Lykoudis, S., Lisaridis, I., Gerasopoulos, E., Kouvarakis, G., Petrakis, M., and C. Zerefos: The effect of the total solar eclipse of 29 March 2006 on meteorological variables in Greece, Atmos. Chem. Phys. Discuss., 7, 10 631-10 667, 2007.

Lelieveld, J., Berresheim, H., Borrmann, S., Crutzen, P. J., Dentener, F. J., Fischer, H., Feichter, J., Flatau, P. J., Heland, J., Holzinger, R., Korrmann, R., Lawrence, M. G., Levin, Z., Markowicz, K. M., Mihalopoulos N., Minikin, A., Ramanathan, V., De Reus, M., Roelofs, G. J., Scheeren, H. A., Sciare, J., Schlager, H., Schultz, M., Siegmund, P., Steil, B., Stephanou, E. G., Stier, P., Traub, M., Warneke, C., Williams, J., and Ziereis, H.: Global air pollution crossroads over the Mediterranean, Science, 298, 794-799, 2002.

Liakakou, E., Vrekoussis, M., Bonsang, B., Donousis, Ch., Kanakidou, M., and Mihalopoulos, N.: Isoprene above the Eastern Mediterranean: Seasonal variation and contribution to the oxidation capacity of the atmosphere, Atmos. Environ., 41, 10021010, 2007.

Liakakou, E.: Factors controlling the variability of NMHCS above the Eastern Mediterranean, $\mathrm{PhD}$ Thesis, University of Crete, 2007.

Poupkou, A., Symeonidis, P., Lisaridis, I., Pouspourika, E., Yay, O. D., Melas, D., Ziomas, I., Balis, D., and Zerefos, C.: Compilation of an emission inventory for the purpose of studying the regional photochemical pollution in the Balkan Region, Proceedings of the Quadrennial Ozone Symposium 2004, Kos, Greece, pp. 902-903, 2004.

Madronich, S.: UV radiation in the natural and perturbed atmosphere, in: Environmental Effects of UV (Ultraviolet) Radiation, edited by: Tevini, M., Lewis Publisher, Boca Raton, pp. 17-69, 1993.

Mavrakis, A., Theoharatos, G., and Lykoudis, S.: Ultraviolet radiation and surface ozone variations during the solar eclipse of 11 Aug. 1999, over Attica, Greece, Proceeding of the XX Quadrennial Ozone Symposium, Vol. II, Session 6, pp. 1126-1127, 2004.

Mihalopoulos, N., Stephanou, E., Kanakidou, M., Pilitsidis, S., and Bousquet, P.: Tropospheric aerosol ionic composition above the Eastern Mediterranean Area, Tellus 49B, 314-326, 1997.

Poisson, N., Kanakidou, M., Bonsang, B., Behmann, T., Burrows, J. P., Fischer, H., Golz, C., Harder, H., Lewis, A., Moortgat, G. K., Nunes, T., Pio, C. A., Platt, U., Sauer, F., Schuster, G., Seakins, P., Senzig, J., Seuwen, R., Trapp, D., Volz-Thomas, A., Zenker, T., and Zitzelberger, R.: The impact of natural non-methane hy- 
drocarbon oxidation on the free radical and ozone budgets above a eucalyptus forest, Chemosphere-Global Change Science, 3, 353-366, 2001.

Sciare, J., Kanakidou, M., and Mihalopoulos, N.: Diurnal and seasonal variation of atmospheric dimethyl sulfoxide (DMSO) at Amsterdam island in the southern indian ocean, J. Geophys. Res., 105, 17 257-17 265, 2000a.

Sciare, J., Baboukas, E. D., Kanakidou, M., Kriscke, U., Belviso, S., Bardouki, H., and Mihalopoulos, N.: Spatial and temporal variability of atmospheric sulfur containing gases and particles during the Albatross campaign, J. Geophys. Res., 105, 14433 14 448, 2000 b.

Srivastava, G. P., Pakkir, M. P. M., and Balwalli, R. R.: Ozone concentration measurements near the ground at Raichur during the solar eclipse of 1980, Proceedings of Indian Natural Sciences Academy, A48(3), 138-142, 1982.

Tsigaridis, K. and Kanakidou, M.: Importance of Volatile Organic Compounds Photochemistry Over a Forested Area in Central Greece, Atmos. Environ., 36, 19, 3137-3146, 2002.

Vrekoussis, M., Kanakidou, M., Mihalopoulos, N., Crutzen, P. J., Lelieveld, J., Perner, D., Berresheim, H., and Baboukas, E.: Role of the $\mathrm{NO}_{3}$ radicals in oxidation processes in the eastern Mediterranean troposphere during the MINOS campaign, Atmos. Chem. Phys., 4, 169-182, 2004,

http://www.atmos-chem-phys.net/4/169/2004/.
Vrekoussis, M., Liakakou, E., Mihalopoulos, N., Kanakidou, M., Crutzen, P. J., and Lelieveld, J.: Formation of $\mathrm{HNO}_{3}$ and $\mathrm{NO}_{3}^{-}$in the anthropogenically-influenced eastern Mediterranean marine boundary layer, Geophys. Res. Lett., 33, L05811, doi:10.1029/2005GL025069, 2006.

Vrekoussis, M., Mihalopoulos, N., Gerasopoulos, E., Kanakidou, M., Crutzen, P. J., and Lelieveld, J.: Two-years of $\mathrm{NO}_{3}$ radical observations in the boundary layer over the Eastern Mediterranean, Atmos. Chem. Phys., 7, 315-327, 2007, http://www.atmos-chem-phys.net/7/315/2007/.

Zanis, P., Zerefos, C. S., Gilge, S., Melas, D., Balis, D., Ziomas, I., Gerasopoulos, E., Tzoumaka, P., Kaminski, U., and Fricke, W.: Comparison of measured and modelled surface ozone concentrations at two different sites in Europe during the solar eclipse on August 11, 1999, Atmos. Environ., 35, 4663-4673, 2001.

Zerefos, C. S., Balis, D. S., Zanis, P., Meleti, C., Bais, A. F., Tourpali, K., Melas, D., Ziomas, I., Galani, E., Kourtidis, K., Papayannis, A., and Gogosheva, Z.: Changes in surface UV solar irradiance and ozone over the Balkans during the eclipse of August 11, 1999, Adv. Space Res., 27(12), 1955-1963, 2001.

Zerefos, C. S, Balis, D. S., Meleti, C., Bais, A. F., Tourpali, K. Vanicek, K., Cappelani, F., Kaminski, U., Tiziano, C., Stubi, R., Formenti, P., and Andreae, A.: Changes in environmental parameters during the solar eclipse of August 11, 1999, over Europe, Effects on surface UV solar irradiance and total ozone, J. Geophys. Res., 105, 26463-26 473, 2000. 